\title{
Kamu Çalışanlarının Yaşam Memnuniyeti Düzeyinin Göç Etme Niyeti Üzerine Etkisi: Tortum İlçesi Örneği *
}

\section{The Effect Of Life Satisfaction Of Public Employees On The Intention Of Migration: The Example Of Tortum District}

\author{
Adnan KÜÇÜKALía \\ Sibel BAKAN ATASEVER ${ }^{b}$ \\ a a Doc.Dr. , Atatürk Üniversitesi, \\ Erzurum, Türkiye, \\ adnankucukali@atauni.edu.tr, ORCID: \\ 0000-0002-3908-3400 \\ b Doktora Öğrencisi. , Erzurum, \\ Türkiye, sbl_bkn90@hotmail.com , \\ ORCID: 0000-0001-5721-0963
}

\begin{abstract}
ÖZ
Türkiye'nin Doğu ve Güneydoğu Bölgeleri özel de ise Erzurum ve ilçeleri, artış hızı yıllara göre değişkenlikler gösterse de, son yarım yüzyıl göçün değişmez adresi olmuştur. Göç, ilk bakışta bireylerde yaşanılan mekân değişikliği olarak kendini gösterse de, birç̧ok soruna kaynaklık etmesi nedeniyle aynı zamanda toplumsal bir sorundur. $\mathrm{Bu}$ araştırma, kamu çalışanlarının yaşam memnuniyeti düzeylerinin göç etme niyeti üzerine olan etkisini tespit etmek amacıyla yapılmıştır. Araştırma ile Erzurum ili Tortum İlçesinde görev yapmakta olan 136 kamu çalışanının memnuniyet düzeyleri anket uygulaması aracılığıyla tespit edilmiştir. Toplanan veriler analiz edilerek yaşam memnuniyeti düzeyinin artmasının göç etme niyeti üzerine negatif yönde etki ettiği sonucuna ulaşılmıştır. Göç etme niyetinin ortaya çıkmasında sosyal çevrenin kısıtlılı̆̆ı, bölgenin sosyoekonomik düzeyinin düşüklüğü, sosyal, kültürel ve sanatsal etkinliklerin yetersizlikleri temel nedenler arasında yer almıştır.
\end{abstract}

Anahtar Kelimeler: Göç, Yaşam Memnuniyeti, Sosyo-Ekonomik Yapı, Kamu Çalışanları, Sosyal Politika. .

\begin{abstract}
The Eastern and Southeastern Regions of Turkey, in particular Erzurum and its districts, have been the constant address of immigration for the last half century, although the rate of increase varies according to years. Although migration manifests itself as a change of place experienced by individuals at first glance, it is also a social problem because it is the source of many problems. This research was conducted to determine the effect of life satisfaction levels of public employees on their intention to migrate. With the research, the satisfaction levels of 136 public employees working in Tortum District of Erzurum province were determined through the survey application. By analyzing the collected data, it was concluded that the increase in the level of life satisfaction had a negative effect on the intention to migrate. The limitation of the social environment, the low socioeconomic level of the region, the inadequacy of social, cultural and artistic activities were among the main reasons for the emergence of the intention to migrate.
\end{abstract}

Keywords: Migration, Life Satisfaction, Socio-Economic Structure, Public Employees, Social Policy.

\footnotetext{
* Bu makalede bilimsel araştırma ve yayın etiği ilkelerine uyulmuştur. / In this article, the principles of scientific research and publication ethics were followed.

Atıf-Reference: Küçükali, A. \& Bakan Atasever, S. (2021). Kamu Çalışanlarının Yaşam Memnuniyeti Düzeyinin Göç Etme Niyeti Üzerine Etkisi: Tortum İlçesi Örneği. Bitlis Eren Üniversitesi Sosyal Bilimler Dergisi, 10 (2), 81-91.
} 


\section{GíRiş}

Memnuniyet olgusu, gereksinim ve isteklerin karşılanmasından doğan tatmin olma duygusu iken yaşam memnuniyeti, insanın kendi yaşam kalitesini tümüyle değerlendirmesi sonucunda ulaştığı olumluluk derecesi anlamı taşımaktadır (Kahyaoğlu, 2008: 22). Genel olarak, yaşam memnuniyetinin yüksek olması, yaşam kalitesini de olumlu yönde etkilemektedir. Yaşam memnuniyetinde bireysel ve özel alan ile özel olmayan kamuya ait daha genel alanlar bireyin yaşam kalitesini beraberce oluşturmaktadır. Bu anlamda kişinin yaşı, yaşam şekli, kişisel özellikleri gibi faktörler, öznel faktörler iken kişinin başarısı, bireylerle kurduğu sosyal ilişkiler ise yaşam memnuniyetini etkileyen toplumsal faktörler içerisinde yer almaktadır (Boylu ve Paçacioğlu, 2016: 13-142).

Bireyler, doğal olarak elde etmeyi istediği ve ulaşmayı hedeflediği yüksek düzeyde yaşam memnuniyetine sahip olabilmenin çabası içerisindedir. Hemen her bireyde farklılıklar gösterebilen memnuniyet düzeylerinin oluşumunda genel geçer standartlar yoktur ve bireysel farklılıklar memnuniyet düzeylerinde farklılık gösterebilmede etkili olabilmektedir.

Bireyler yaşamlarını daha kaliteli bir hale getirmek ve birtakım imkânlara ulaşabilmek için zaman zaman farklı bir mekân veya coğrafyada yaşama ihtiyacı duyabilmektedir. Bu gereksinimi karşılamanın en önemli yollarından birisi de göçtür. Göç, uluslararası boyutu olan bir olgu olduğu gibi ulusal sınırlar içerisinde de olabilmektedir. Göç kavramı, coğrafi mekân değiştirme süreci olarak tanımlanabilmektedir (Taş ve Özcan, 2013: 289). Göç olayı gerçekleştikten sonra göçün ekonomik, sosyal, kültürel, politik boyutu hem göç edenler hem de bölgede kalıp yerleşik durumda olan halk üzerinde etkiler bırakabilmektedir. Farklı nedenlerden kaynaklanabilen göç, temel olarak sosyal yapıdaki değişimlerden, mevcut alandaki emek arzı fazlalığından ve sosyo-ekonomik açıdan daha gelişmiş alanlardaki daha konforlu yaşam olanaklarından etkilenebilmektedir. Bireylerin bulundukları yerdeki yaşamlarını olumsuz değerlendirmeleri, bireylerin yer değiştirme kararı almalarına sebep olabilmektedir. $\mathrm{Bu}$ anlamda yaşam memnuniyeti ve göç birbirinin hem sebebi hem de sonucu olma niteliğine sahiptir. Bireylerin yaşadıkları çevreden memnuniyeti aynı zamanda sosyal politikanın temel problemlerinden olan şehirlerden göçü ve bölgesel gelişmişlik düzey farklılıklarını gidermede de oldukça önemli bir argümandır.

Artış hızında yıllara göre değişimler yaşansa da son kırk yıl içerisinde Doğu Anadolu Bölgesi özelde ise Erzurum ve ilçeleri, iç ve dış göçün değişmez adreslerinden biri olmuştur. Erzurum Türkiye'de göç veren illerin başında yer almakta ve bu durum bölgesel gelişme ve kalkınma ile birlikte şehirde yaşayanların şehirden beklentilerini ve yaşama arzularını da olumsuz yönde etkilemektedir (Küçükali, 2018: 590).

$\mathrm{Bu}$ araştırma, Tortum ilçesinde istihdam edilen kamu çalışanlarının göç etme niyetini etkileyen faktörleri ortaya çıkarmak ve yaşam memnuniyet düzeylerini tespit edebilmek amacıyla yapılmıştır. 2019 yılı içerisinde ilçe merkezinde çalışmakta olan kamu emekçilerine uygulanan anketle, ilçedeki bir takım kısıtlı imkânların ilçeden memnuniyeti olumsuz etkilediği, bu durumun da göç etme niyetini artırdığının tespiti yapılmıştır. Ayrıca memnuniyetin artırılması amacıyla yapılacak olan uygulama ve tedbirler, göç etme niyetini azaltma yönünde etkili olabileceğinden ilçenin bu anlamda farklı politikalara ihtiyacı olduğunu ortaya çıkararak politika yapıcıların değerlendirmelerine zemin hazırlanmıştır.

\section{YASAM MEMNUNIYYTİ}

Literatürde yaşam kalitesi, mutluluk, iyilik gibi kavramlarla ifade edilen yaşam memnuniyeti kavramı, 1970'li yıllardan sonra sosyoloji, psikoloji ve sosyal psikoloji alanında çalışılmaya başlanan konular arasında yer almaya başlamıştır (Öztürk, 2015: 44).

Yaşam memnuniyeti, bireyin genel anlamda yaşamından duyduğu memnuniyet olarak tanımlanmaktadır (Bülbül \& Giray, 2012: 102). Diğer bir tanımda ise, yaşam memnuniyeti kavramı, bireyin yaşam kalitesini bir bütün olarak ya da yaşamın belirli alanları ile bilişsel olarak değerlendirmesi şeklinde ifade edilmektedir (Behlau, 2010: 8). Çoğu zaman mutluluk olarak adlandırılan yaşam memnuniyeti, geçmişten günümüze insanlığın ilgi odağı olan ve araştırılan konulardan biri haline gelmiştir. Mutluluk, bireyin yaşam ve yetişme tarzının, çevresinin, aile yapısının, içsel dünyasının, arzularının, ihtiyaçlarının, duygularının ve hatta bütün olanaklarının büyük bir uyum içinde dengesini bulması ile oluşacak bir ruh hali olarak da ifade edilebilmektedir. Günlük hayatta kullanılan mutluluk kavramı, açıklanması güç ve çeşitli anlamlara gelen bir kavram olduğu için sosyal psikologlar mutluluk yerine yaşam doyumu ya da yaşam memnuniyeti kavramlarını kullanmaktadır (Kahyaoğlu, 2008: 23). 1970'li yıllara kadar bilimsel anlamda üzerinde pek durulmayan mutluluk kavramı, 1974 yılında sadece mutluluk çalışmalarının yayınlandığı uluslararası bir derginin yani Journal of Happiness Studies'in yayın hayatına başlamasıyla üzerinde yoğun çalışmalar sürdürülmeye başlanan bir kavram olmuştur (Yücel, 2017: 25).

Yaşam memnuniyeti cinsiyetten medeni duruma, eğitime ve açıkçası yaşamı oluşturan çok çeşitli faktörlerden etkilenmektedir. Literatür incelendiğinde bu faktörlerin farklı şekillerde gruplandırıldığı gözlemlenmektedir. Bjornskov ve diğerleri 2008 yılında yaptıkları bir çalışmada yaşam memnuniyetini etkileyen faktörleri; ekonomik, siyasi, kurumsal ve kültürel olmak üzere dört ana grupta toplamıştır (Bjornskov vd., 2008: 122-129). Jagodzinski, yaşam memnuniyetini etkileyen faktörleri ekonomik, toplumsal ve kültürel faktörler şeklinde üç temel grupta sınıflandırmıştır (Jagodzinski, 2010: 89-93). Frijns ise bu faktörleri, mikro-sosyal ve makro-sosyal faktörler olarak iki ana grupta ele almıştır (Frijns, 2010: 10-23). Ragheb ve Griffith (1982) ise, 55 yaş ve üzerindeki insanlar için boş vakit ile yaşam memnuniyeti arasındaki ilişkiyi incelemiş ve boş vakit ile yaşam memnuniyeti arasında pozitif bir ilişkinin olduğu sonucunu ortaya koymuştur (Ragheb \& Griffith, 1982: 295-306).

\section{GÖÇ VE GÖÇ OLGUSU}

İnsanlığın tarih sahnesinde yer aldığı ilk zamanlardan bu yana yer değiştirme hareketi olarak ifade edilen göçlerin içeriği ve niteliği sürekli olarak değişim göstermiştir (Koçak \& Terzi, 2012: 165). İlk zamanlarda iklim koşulları, savaş ya da kıtlık gibi sebeplerle oluşan yer değiştirme hareketleri zaman içerisinde yerini toplumsal, kültürel, politik ya da eğitim gibi nedenlere bırakmaktadır. Bu sebeple geçmişten günümüze yapılan ve gelecekteki olası göç hareketleri uzmanların dikkatini çekmiş, 
konuyla alakalı çeşitli tanımların yapılmasına neden olmuştur (Çakı, 2018: 8-9). Birleşmiş Milletler'e göre göç kavramı, bireyin ya da bir grup insanın bulunduğu coğrafi birimden başka bir coğrafi birime, kendi ülkesinden farklı bir yerde geçici ya da daimi olarak ikamet etmek üzere siyasi ve yönetsel sınırı aşarak geçmesi olarak tanımlanmaktadır (Paydak, 2012: 13). Uluslararası göç örgütü ise göç kavramını, uluslararası bir sınırı geçerek ya da ulusal sınırlar içerisinde süresi, yapısı ve nedeni ne olursa olsun insanların yer değiştirmesi hareketi olarak ifade etmektedir (Erol \& Ersever, 2014: 49). Göç kavramı, insanların dini, ekonomik, politik, toplumsal ve diğer nedenlerden dolayı hayatlarının bir bölümünü ya da tümünü geçirmek üzere bir mekândan başka bir mekâna yerleşmek suretiyle yaptıkları yer değiştirme durumu olarak ifade edilebilmektedir (Sayın vd., 2016: 2; Küçükali, 2016: 3). Göç kavramı, küresel politika, ekonomi, iklim, sosyal ve kültürel faktörler tarafından belirlenen dinamik bir olguyu da temsil etmektedir (Marian, 2015: 450). Göçün komplike ve değişkenlik gösteren yapısı tanımlanmasını da güçleştirmektedir (Yenginar, 2019: 6-7). Eski dönemlerden beri süregelen göç olgusu, günümüzde küreselleşmenin etkisiyle, hareketliliğini ve mesafesini olağanüstü şekilde artırarak daha büyük kitlesel hareketler haline gelmiştir. Bu durum, göçe dair tanımlarda da farklılığa yol açmakta ve göç hareketlerinin gruplandırılmasında da bu farklılığa rastlanmaktadır. Geniş anlamda göçü, yer değiştirme hareketi, toplumların demografik, sosyo-ekonomik ve kültürel yapısı ile bunların oluşumunu biçimlendiren dinamik bir süreç olarak kabul etmek doğru bir yaklaşım olarak görülebilir. Ayrıca göç, temel insan haklarından yaşam hakkı, can ve mal güvenliği hakkı gibi oldukça geniş bir yelpazede etkin olan bir olgudur (Akıncı, Nergiz \& Gedik, 2015: 61-62).

Göçe sebep olan faktörler, göç süresi ve sonrasındaki gelişmeleri büyük oranda etkilemektedir. Ekonomik kaynaklı göçler, siyasi kaynaklı göçlerden farklı bir sürecin işlemesine sebep olabileceği gibi farklı ekonomik, toplumsal ve siyasi sonuçların ortaya çıkmasına da sebep olabilmektedir (Tolstrup, 2016: 15; Ekici \& Tuncel, 2015: 13).

Küreselleşme ve kapitalizmin etkisiyle dünyanın bazı bölgelerinin aşırı gelişmiş olması, diğer bölgelerin ise gelişmemiş veya az gelişmiş olması, bölgesel kalkınmışlık düzeyleri arasındaki dengesizlikleri büyütmüştür. Bu durum, Batı’yı özelde ise kuzey yarım küreyi diğer toplumlar için çekim merkezi haline getirmiştir (Topçu ve Beşer, 2006: 38).

Yeryüzünde yaşanmakta olan küresel göç olgusu, günümüzde birden fazla unsuru içinde barındıran hem devletleri hem de sıradan bireyleri etkisi altına alan kompleks ve ciddi problemleri de beraberinde getiren bir kavram olarak karşımıza çıkmaktadır (Çınar, 2018: 5-6). Bu haliyle göç, süreci, maliyeti, nedenleri, sonuçları ve etkileriyle kolayca sosyal politika disiplinin ilgi alanı içerisinde kendisine yer bulabilmiştir. Her nerede bir göç olayı ortaya çıkarsa hem göç alan birim hem de göç veren birimin çok yönlü bir şekilde etkilendiği gerçekliğiyle de karşılaşılır. Genel olarak göç eden bireyler göç koşullarına ayak uydurabilecek güçte olmalarından veya göç edilecek yerde yetenekleri ile var olabileceğinden üretken nüfus, gelen göçle birlikte kaybedilebilmektedir. Ucuz üretken işgücü mevcut işgücünde yoksullaşmanın nedeni olmaya başlayabilir. Bu durum yoksullaşan ve iş bulmakta zorluk çeken yerleşik işgücünün daha farklı yerlere yönelmesi, göç etmesiyle de sonuçlanabilir (Can, 2011: 16).

Göçü veren birimde harcama ya da birikim yapan insanların başka yere geçmesi, sermayenin ve diğer ekonomik kaynakların belli kentsel alanlara akarak oralarda toplanmasına sebep olmakta buna bağlı olarak da göç veren birimin gelişim hızı düşüş göstermektedir. Ekonomik rekabette göç nedeniyle geriye düşen birim zamanla daha az istihdam alanları yaratacağından bölgede göç olayı süreklilik kazanacağı gibi ekonomik düzeydeki düşüş kronikleşecektir. Daha ziyade kent merkezlerinde yoğunlaşan göç, istihdama, kentsel işgücüne, gelir dağılımına, kentin fiziki ve sosyo-kültürel yapısına ayrıca kentin yönetimine etkileri nedeniyle özellikle sosyolojinin ve sosyal politikanın araştırma alanları içerisindedir. Zira göç ile beraber tüm bu alanlarda göç öncesi mevcut kurulu düzenin sarsılmasına ve yeni dengeler üzerinde farklı oluşumların gerçekleşmesine yol açmaktadır (Çelebi, 2016: 18-20).

\section{YAŞAM MEMNUNIYETI VE GÖÇ ILIŞSISİ}

İnsanlar savaş, doğal afet gibi nedenler dışında genel olarak refahlarını arttırmak ve daha iyi yaşam koşullarına kavuşmak amacıyla göç etmektedir. İnsanların asıl hedefi, göç vasıtasıyla mutluluğunu arttırmaktır. Göç bu anlamda amaç değil, bir araç olarak görülmektedir (Gül, 2017: 70.).

Göç kavramının temelinde yatan düşünce, standart olan yaşam kalitesinin arttırılmasıdır. Bilhassa, kıt kaynakların paylaşımındaki dengesizlik bireyleri göç etme noktasında zorlayıcı olmaktadır. Göç edilen yere nazaran, yeni yerleşilen birimlerde daha fazla elde edilmesi ümit edilen kaynaklarla yaşam memnuniyetinin artış göstereceği düşünülmektedir (Arslan, 2012: 36).

Yaşam kalitesi, çevrenin ölçülebilir mekânsal, fiziksel, sosyal bileşenleri ve bu söz konusu bileşenlerin algılama biçimlerini birlikte ele alan ve bireylerin algılama biçimlerinin sadece nesnel özellikleri ile değil, bireysel etkilerin de değerlendirildiği bir yaklaşımla ele alınmaktadır. Hava, su ve gürültü kirliliği, katı atık, iklim, eğlence yerleri ve etkinlikleri, aile yaşamı, evlilik, iş, boş zaman, konut, sağlık ve çevre, ulaşım, eğitim, ekonomi, sosyal çevre, bireyin karakteri ve yetenekleriyle ilgili bireysel faktörlerin etkisi ve fiziksel, çevresel etmenler yaşam kalitesinin kriterleri olarak ifade edilmektedir (Atik, Taçoral \& Altunkasa vd., 2014: 22).

Literatürde, sosyo-ekonomik ve coğrafi faktörlerin göç niyetinin oluşumundaki etkilerini araştıran, birçok çalışmanın olduğu görülmüştür. Bu bağlamda, göç olgusunu inceleyen çalışmalara Küçükali (2018)'nin “Akademisyenlerde Göç Etme Niyeti; Erzurum İli Örneği, Koçak ve Terzi (2012)’nin “Türkiye’de Göç Olgusu, Göç Edenlerin Kentlere Olan Etkileri ve Çözüm Önerileri”, Uzun (2018)’un “Küreselleşme Sürecinde Göç Olgusu; Göçün Stratejik Yönetimi ve Türkiye Örneği”, Eraldemir (2013)'in “Türkiye’de Göç Sorunu, Göçlerin Sosyoekonomik Yansımaları: İskenderun-Dörtyol Örneğì”, Kaya (2001)’nın “Göç ve Sosyal Bütünleşme (Akarca Köyü Örneği) adlı çalışmaları örnek verilebilir. 
Literatürde karşılaşılan çalışmalar daha ziyade bölgesel alan araştırması niteliğindedir. Bu çalışmaların ortak özellikleri, göç niyeti” oluşumuna neden olan faktörleri belirlemek ve göçün devamını sağlayan olumsuzlukların ortadan kaldırılması/azaltılabilmesi için yapılabilecekleri ortaya çıkarma amaçlıdır.

Türkiye'de yaşam memnuniyeti ile ilgili birçok araştırma yapılmasına rağmen yaşam memnuniyeti ve göç kavramlarının birlikte incelendiği çalışmaların sayısı azdır. Yaşam memnuniyeti ile ilgili çalışmalara; Yetim (2018)'in "Yaşam Memnuniyeti ve Yaşam Kalitesinin Belirleyicileri: Sağlık Hizmetlerinden Memnuniyet ve Sağlık Statüsünün Rolü’, Kahyaoğlu (2008)’nun "Yaşam Memnuniyeti ve Yaşam Memnuniyetini Etkileyen Değişkenler ile Ekonometrik Uygulama: Türkiye Örneği”, Korkmaz vd. (2015)'nin “Yaşam Memnuniyeti Üzerinde Etkili Olan Sosyodemografik Bileşenler Üzerine Bir Analiz”, Sezmez (2018)'in “Çevre Bilincinin Yaşam Memnuniyeti Üzerindeki Etkisi: Edirne, Uzunköprü İlçesi Örneği”, Arı ve Y1ldız (2016)’ın “Bireylerin Yaşam Memnuniyetini Etkileyen Faktörlerin Sıralı ve Lojistik Regresyon Analizi ile İncelenmesi” adlı çalışmalar örnek verilebilir.

Bölgesel kalkınmışlık düzeylerinin çok daha fazla bozulmasına ve farklılık göstermesine neden olan göçler, alan odaklı araştırmalara konu edildikçe göçü önlemeye yönelik politikaların hazırlanmasına olumlu katkılar sağlanacaktır.

\section{ARAŞTIRMA}

\subsection{Araştırmanın Amacı ve Önemi}

Bu araştırmanın amacı, Erzurum ili Tortum ilçesinde hizmet vermekte olan kamu çalışanlarının göç etme niyetini etkileyen faktörleri ortaya çıkararak çalışanların yaşam memnuniyeti düzeylerinin, göç etme niyeti üzerine etkisini belirlemektir.

Bölgesel gelişmişlik düzeyini olumsuz yönde etkileyecek ve ulusal bir sorun olma özelliğine sahip göç olgusunun araştırılması, özellikle sosyal politika bilimi ve uygulayıcıları açısından ayrıcalıklı bir öneme haizdir.

\section{2. Ön Kabuller ve Sinırlılıklar}

Veriler toplanırken araştırmaya katılan çalışanlara anketten elde edilecek verilerin sadece bilimsel amaçla kullanılacağı belirtilmiştir. Bu sebepten dolayı katılımcıların anket sorularına doğru yanıt verdikleri kabul edilmektedir. Sosyal bilimlerdeki araştırmalara özgü sınırlılıklar, bu araştırma için de söz konusudur.

\subsection{Araştırmanın Yöntemi}

Bu araştırma, betimsel bir araştırmadır. Bu bölümde, araştırmanın evren ve örneklemi, anketin uygulanması, verilerin toplanması ve veri toplamada kullanılan yöntem ve analizler üzerinde durulmuştur.

\subsubsection{Araştırma Evreni ve Örneklemi}

Bu çalışma, daha önceden 2015 yılında Erzurum merkezde yapmış olduğumuz 2018 yılında yeni verilerle güncellenmiş olarak yayınladığımız (Küçükali, 2018: 588-608), göç çalışmalarımızın ilçe düzeyinde farklı kamu çalışanlarıyla gerçekleştirilen yeni bir araştırma halkası olma durumundadır.

Araştırmanın çalışma evreni, 29 Temmuz - 2 Ağustos 2021 yılında Erzurum ili Tortum ilçe merkezinde (çevre mahalleler hariç) hizmet veren (öğretmen, polis, hemşire, doktor, askeri personel ve diğer kurum çalışanları) kamu çalışanlarıdır. Örneklem seçiminde tesadüfi örnekleme yöntemlerinden basit tesadüfi örnekleme yöntemi tercih edilmiştir. Araştırmanın çalışma evrenini254 kamu çalışanı oluşturmaktadır. Ana kütleyi oluşturan her elemanın örneğe girme şansını, eşit kılan basit tesadüfî örnekleme yöntemine başvurularak 254 çalışana anket uygulanmıştır. Anket sonucunda 136 çalışandan cevap alınabilmiştir. Araştırmaya konu olan anket sayısı 136 olarak gerçekleşmiştir.

\subsubsection{Veri Toplamada Kullanılan Ölçekler}

Araştırmada veri toplama aracı olarak anket formu kullanılmıştır Anketle elde edilen veriler bilgisayar ortamına, SPSS for Windows 16.0 programı ile aktarılmış ve istatistiksel analizlerde frekans, yüzde dağılımları, ortalama ve standart sapma kullanılmıştır.

Anket, iki bölümden oluşmaktadır. Birinci bölümde; katılımcıların demografik bilgileri, iskân, mülkiyet ve akrabalık durumlarının tespitine çalışılmıştır. İkinci bölümde ise göç etme niyeti ve yaşam memnuniyetine ilişkin yaklaşımları incelenmiştir. Toplam 50 sorudan olan anket formu, Tortum İlçe merkezinde istihdam olunan ve katılım teklifine olumlu yanıt veren kamu personeli ile gerçekleştirilmiştir.

$\mathrm{Bu}$ araştırmada göç etme niyeti ve yaşam memnuniyeti olmak üzere iki ayrı ölçekten yararlanılmıştır. Sorular Küçükali’nin göçü araştırma konusu edindiği "Bir Sosyal Politika Problemi Olarak Göç (Erzurum Örneği)” adlı kitabından alınmıştır (Küçükali, 2016: 46).

Yaşam memnuniyeti sorularının temel alındığı ölçek 5'li likert ölçeği (1=Çok Düşük, 2= Düşük, 3= Orta Düzeyde, 4= Yüksek, 5= Çok Yüksek) şeklinde ve 19 sorudan oluşmaktadır. Göç etme niyeti sorularının temel alındığı ölçek de 5'li likert ölçeği (1= Kesinlikle Katılmıyorum, 2= Katılmıyorum, 3=Kararsızım, 4= Katılıyorum, 5= Kesinlikle Katılıyorum) şeklinde ve 16 sorudan oluşmaktadır.

Ölçeğin alfa katsayısı ne kadar yüksek olursa bu ölçekte bulunan maddelerin o ölçüde birbirleriyle tutarlı olduğu ve aynı özelliğin öğelerini yoklayan maddelerden oluştuğu şeklinde yorumlanmaktadır. Alfa katsayısına bağlı olarak ölçeğin güvenilirliği Tablo 1'deki gibi değerlendirilmiştir. 
Tablo 1: Cronbach $\alpha$ Değerlerine Göre Güvenirlik Düzeyleri

\begin{tabular}{|c|c|}
\hline Cronbach $\boldsymbol{\alpha}$ Değeri & Güvenirlik Düzeyi \\
\hline $\mathbf{1 . 0 . 8 0} \leq \boldsymbol{\alpha} \leq \mathbf{1}$ & Yüksek \\
\hline $\mathbf{0 , 6 0} \leq \boldsymbol{\alpha} \leq \mathbf{0 , 8 0}$ & Oldukça \\
\hline $\mathbf{0 , 4 0} \leq \boldsymbol{\alpha} \leq \mathbf{0 , 6 0}$ & Düşük \\
\hline $\mathbf{0} \leq \boldsymbol{\alpha} \leq \mathbf{0 , 4 0}$ & Güvenilir Değil \\
\hline
\end{tabular}

Araştırmanın anketinde bulunan göç etme niyeti bölümünün likert ölçekli 16 sorusu ile yaşam memnuniyeti bölümünün likert ölçekli 19 sorusuna ait Cronbach Alfa güvenilirlik analizi sonuçları Tablo 2'de verilmiştir. Göç etme niyeti altındaki 16 soruya ait genel Alfa katsayısı 0,850'dir. Tablo 2'te yer alan güvenirlik düzeyi kriterlerine göre; göç etme niyeti ölçeğinin güvenirlik düzeyi yüksek olup, geçerli ve güvenilir bir ölçektir. Aynı şekilde yaşam memnuniyeti altındaki 19 soruya ait genel alfa katsayısı 0,898 olarak bulunmuştur. Güvenirlik düzeyi kriterlerine göre; yaşam memnuniyeti ölçeğinin güvenirlik düzeyi yüksek olup, geçerli ve güvenilir bir ölçektir (Küçükali, 2018: 587-607).

Tablo 2: Araştırmada Kullanılan Likert Ölçekli Soru Gruplarının Güvenirlik Analizi Sonuçları

\begin{tabular}{|l|c|c|}
\hline \multicolumn{1}{|c|}{ Ölçek Adı } & Cronbach Alfa Katsayısı & Madde Sayısı \\
\hline Göç Etme Niyeti & 0,850 & 16 \\
\hline Yaşam Memnuniyeti & 0,898 & 19 \\
\hline
\end{tabular}

Anketlerin analizinin yapılmasında SPSS for Windows 16.0 paket programı kullanılmıştır. Elde edilen bilgiler, daha anlaşılır olabilmesi amacıyla istatistiksel olarak sunulmuştur.

\subsection{Araştırma Bulguları ve Yorumlar}

Tablo 3: Katılımcıların Demografik Özelliklerine Ait Frekans Dağılımı

\begin{tabular}{|c|c|c|}
\hline Katılımcıların Demografik Özellikleri & Frekans & Yüzde (\%) \\
\hline $\begin{array}{l}\text { Cinsiyet: } \\
\text { Kadın } \\
\text { Erkek } \\
\text { Üçüncü cinsiyet }\end{array}$ & $\begin{array}{c}29 \\
107 \\
0 \\
\end{array}$ & $\begin{array}{c}21,3 \\
78,7 \\
0 \\
\end{array}$ \\
\hline $\begin{array}{l}\text { Yas Aralığı: } \\
18-25 \\
26-35 \\
36-45 \\
46-55 \\
56-65\end{array}$ & $\begin{array}{c}18 \\
77 \\
25 \\
11 \\
5 \\
-\end{array}$ & $\begin{array}{c}13,2 \\
56,6 \\
18,4 \\
8,1 \\
3,7 \\
-\end{array}$ \\
\hline $\begin{array}{l}\text { Medeni Durum: } \\
\text { Evli } \\
\text { Bekâr }\end{array}$ & $\begin{array}{l}84 \\
52\end{array}$ & $\begin{array}{l}61,8 \\
38,2\end{array}$ \\
\hline $\begin{array}{l}\text { Cocuk Sayısı: } \\
\text { Yok } \\
1 \\
2 \\
3 \\
4 \\
5 \text { ve üzeri }\end{array}$ & $\begin{array}{c}64 \\
29 \\
27 \\
14 \\
2 \\
-\end{array}$ & $\begin{array}{c}47,1 \\
21,3 \\
19,9 \\
10,3 \\
1,5 \\
-\end{array}$ \\
\hline $\begin{array}{l}\text { Ĕgitim Durumu: } \\
\text { İlkokul } \\
\text { Ortaokul } \\
\text { Lise } \\
\text { Ön Lisans } \\
\text { Lisans } \\
\text { Yüksek Lisans } \\
\text { Doktora }\end{array}$ & $\begin{array}{c}- \\
- \\
35 \\
26 \\
61 \\
14 \\
-\end{array}$ & $\begin{array}{c}- \\
- \\
25,7 \\
19,1 \\
44,9 \\
10,3 \\
-\end{array}$ \\
\hline $\begin{array}{l}\text { Doğum Yeri: } \\
\text { Tortum } \\
\text { Diğer }\end{array}$ & $\begin{array}{l}39 \\
97\end{array}$ & $\begin{array}{l}28,7 \\
71,3\end{array}$ \\
\hline
\end{tabular}




\begin{tabular}{|c|c|c|}
\hline $\begin{array}{l}\text { Eslerinin Doğum Yeri } \\
\text { Tortum } \\
\text { Diğer } \\
\text { Bekâr }\end{array}$ & $\begin{array}{l}22 \\
62 \\
52\end{array}$ & $\begin{array}{l}16,2 \\
45,6 \\
38,2\end{array}$ \\
\hline Toplam & 136 & 100 \\
\hline
\end{tabular}

Araştırmaya katılan katılımcıların cinsiyet dağılımına bakıldığında kadın katılımcıların \%21,3 ve erkek katılımcıların ise \%78,7'lik orana sahip olduğu görülmektedir. Bu oranlar dikkate alındığında erkek kamu çalışanların kadın kamu çalışanlarına oranla daha fazla sayıda olduğu anlaşılmaktadır. Katılımcıların yaş aralığında ise en yüksek payı, \%56,6 oranla 26-35 yaş grubuna dâhil olan kamu çalışanlarının aldığı görülmektedir. Yaş aralığının yüzdesel dağılımının, \%18,4 ile 36-45 yaş aralığı, $\% 13,2$ ile 18-25 yaş aralığı, \%8,1 ile 46-55 yaş aralığı ve \%3,7 ile 56-65 yaş aralığına sahip katılımcılardan oluştuğu belirlenmiştir.

Katılımcıların yaş aralıkları itibariyle değerlendirildiğinde en yüksek oranda genç yaş grubuna sahip kamu çalışanları olduğu görülmektedir. Katılımcıların medeni hallerine bakıldığında evli olan katılımcıların oranının \%61,8 olduğu görülmektedir. Bekâr olan katılımcıların oranı ise \%38,2'dir.

Katılımcıların çocuk sayısı dikkate alındığında \%47,1'inin çocuk sahibi olmadığı, \%21,3'ünün 1 çocuk, \%19,9'unun 2 çocuk, \%10,3'ünün 3 çocuk, \%1,5'inin ise 4 çocuk sahibi olduğu görülmektedir.

Katılımcıların eğitim durumlarının dağılımına bakıldığında \%10,3'ünün yüksek lisans, \%44,9'unun, \%25,7'sinin lise, \%19,1'inin ise önlisans mezunu olduğu görülmektedir. Katılımcıların \%28,7'si doğum yerlerini Tortum, \%71,3'ü ise Tortum dışında farklı bir yerleşim bir yerleşim biriminde olarak Katılımcıların eşlerinin doğum yerlerine bakıldığında \%16,2'sinin Tortum doğumlu, \%45,6'sının ise tortum dışı yerleşim yeri olduğu görülmektedir. Katılımcıların \%38,2'si'i ise bekâr olduğundan "eş doğum yeri” bilgisi verememiştir.

Tablo 4: Katılımcıların Çalışma Bilgileri

\begin{tabular}{|c|c|c|}
\hline Tortumda Çalışma Süresi & Frekans & Yüzde (\%) \\
\hline $1-5$ & 98 & 72,1 \\
\hline $6-10$ & 17 & 12,5 \\
\hline 10 yıldan fazla & 21 & 15,4 \\
\hline Toplam & 136 & 100 \\
\hline
\end{tabular}

Katılımcıların Tortum'da çalışma sürelerine bakıldığında \%72,1'i 1-5 yıl, \%15,4'ü 10 yıldan fazla, \%12,5'i ise 6-10 yıl arasında Tortum'!da çalıştıkları gözlemlenmiştir Bölgenin sürekli göç veriyor olması, gerek istihdam edilen personelin yaş ortalamalarının düşük, gerekse de çalışma sürelerinin kısa olmasında belirleyici olduğu görülmektedir.

Tablo 5: Katılımcıların İskân, Mülkiyet ve Akrabalık Durumları

\begin{tabular}{|l|c|c|}
\hline \multicolumn{1}{|c|}{ Katılımcıların İskân, Mülkiyet ve Akrabalık Durumları } & Frekans & Yüzde \% \\
\hline Lojmanda iskân edip/ etmeme durumu: & 26 & 19,1 \\
\hline Evet & 110 & 80,9 \\
\hline Hayır & 26 & 19,1 \\
\hline Tortum'da gayrimenkul sahibi olup/ olmama durumu: & 110 & 80,9 \\
\hline Evet & & \\
Hayır & 41 & 30,1 \\
\hline Tortum dısıında gayrimenkul sahibi olup/ olmama durumu: & 95 & 69,9 \\
\hline Evet & & \\
Hayır & 117 & 86,0 \\
\hline Katılımcının akrabalarının Tortum dıșında iskân etme durumu: & 19 & 14,0 \\
\hline Evet & 72 & 52,9 \\
Hayır & 12 & 8,8 \\
\hline Eșinizin akrabaları Tortum dıșında mı iskân ediyor? & 52 & 38,2 \\
Evet & & \\
Hayır & $\mathbf{1 3 6}$ & $\mathbf{1 0 0}$ \\
\hline Bekâr & & \\
\hline \multicolumn{1}{|c|}{ Toplam } & & \\
\hline
\end{tabular}

Katılımcıların, lojmanda iskân edip etmeme durumunun ölçüldüğü soruya verdikleri cevapta \%19,1'inin lojmanda, \%80,9'u ise lojman dışında iskân ettiği ortaya çıkmıştır. Anket hazırlayıcısının bizzat Tortum ilçesi kamu lojmanlarında ikamet ediyor olması, lojmanlar hakkında bir görüş sahibi olmasına imkân sağlamıştır. İlçede kamu çalışanlarına yetecek miktarda konut olmaması ve metre kare açısından küçük konutların olması, mesken ihtiyacının arzu edilir düzeyde karşılanamadığını göstermektedir.

Diğer farklı yerleşim birimlerinde ve çalışanlarda olduğu gibi sektörler ve yerleşim yerlerindeki çalışanlarda olduğu gibi, elde ettikleri kazançlarının bir kısmını sonucunda elde ettikleri birikimlerini gayrimenkul satın alarak da değerlendirebilmektedir. $\mathrm{Bu}$ yatırımlarını yaşadıkları yerleşim yerlerinde yapabildikleri gibi farklı yerleşim yerlerinde de yapabilmektedirler. Katılımcıların \%80,9'unun Tortum'da gayrimenkul sahibi olmadığı, \%19,1'inin ise Tortum'da gayrimenkul sahibi olduğu 
görülmektedir. Kamu çalışanlarının çoğunluğunun doğum yerinin Tortum dışı olması ve çalışanların sadece \%19,1'inin Tortum'da gayrimenkul sahibi olması, birikimlerini Tortum dışında değerlendirdikleri varsayımını destekler nitelik taşımaktadır. Katılımcıların Tortum dışında gayrimenkul sahibi olma oranı \%30,1, gayrimenkul sahip olmama durumu ise \%69,9’dur.

Erzurum merkezde kamu çalışanlarının göç etme niyeti üzerine yaptığımız araştırmada, çalışanların yerleşim birimlerinde ucuz ve kaliteli konut üretiminin gayrı menkul alımında etkili olacağı ve göç niyetinin önlenmesinde veya ertelenmesinde belirleyiciliği bir rol üstlenebileceği sonucuna ulaşılmıştır (Küçükali, 2018: 587-607).

Katılımcılar, kendi akrabalarının \%86,0’ sının Tortum ilçesi dışında ikamet ettiğini, eşlerinin akrabalarının ise \%52,9'unun aynı şekilde Tortum ilçesi dışında ikamet eteklerini beyan etmişlerdir. Katılımcıların \%38,2'si ise bekâr olduklarından dolayı bu soruya cevap vermemişlerdir.

Tablo 6: Katılımcıların Göç Etme Niyetleri

\begin{tabular}{|l|c|c|}
\hline & Frekans & Yüzde (\%) \\
\hline $\begin{array}{l}\text { Şu anda göç etme niyetinin olup olmadığı } \\
\text { Evet } \\
\text { Hayır }\end{array}$ & 56 & 41,2 \\
\hline $\begin{array}{l}\text { Beş yıl içerisinde göç etme niyetinin olup/olmadığı } \\
\text { Evet } \\
\text { Hayır }\end{array}$ & 80 & 58,8 \\
\hline \multicolumn{1}{|c|}{ Toplam } & 45 & 66,9 \\
\hline
\end{tabular}

Araştırmaya katılan katılımcıların şu andaki göç etme niyetine bakıldığında \%41,2'sinin göç etme niyeti taşıdığı, \%58,8'inin göç etme niyeti taşımadığı görülmektedir. Katılımcıların beş yıl içerisinde göç etme niyeti olup olmadığı dikkate alındığında ise \%69,9’u göç etme niyeti taşımakta, \%33,1'i ise beş yıl içerisinde göç etme niyeti taşımamaktadır. Kamu çalışanlarının şu an göç etme niyetinin düşük olmasına karşın, beş yıl içerisinde göç etme niyetinin yüksek olduğu görülmektedir.

Tablo 7: Katılımcıların Göç Etme Niyetine Etki Eden Faktörler

\begin{tabular}{|c|c|c|}
\hline & Frekans & Yüzde (\%) \\
\hline $\begin{array}{l}\text { Göç etme niyetinin oluşumunda özlük haklarının ve ödeneklerin } \\
\text { belirleyici olup olmadığı } \\
\text { Evet } \\
\text { Hayır }\end{array}$ & $\begin{array}{l}57 \\
79\end{array}$ & $\begin{array}{l}42 \\
58\end{array}$ \\
\hline $\begin{array}{l}\text { İlçede sosyo- kültürel etkinliklerin düzeyinin ve eğitim imkânlarının } \\
\text { göç etme niyetine etkisinin olup olmadığı } \\
\text { Evet } \\
\text { Hayır }\end{array}$ & $\begin{array}{c}105 \\
31\end{array}$ & $\begin{array}{l}77 \\
23 \\
\end{array}$ \\
\hline Toplam & 136 & 100 \\
\hline
\end{tabular}

Araştırmaya katılan katılımcıların göç etme niyetlerinin oluşumunda özlük haklarının ve ödeneklerin belirleyici olup olmadığına bakıldığında \%57'si özlük hakları ve ödeneklerin etkili olduğunu, \%58'i ise özlük hakları ve ödeneklerin etkisinin olmadığını dile getirmektedir. Katılımcıların ilçedeki sosyo-kültürel etkinliklerin ve eğitim imkânlarının göç etme niyetlerine etkisine bakıldığında ise \% 77 'si göç etme niyetleri üzerinde sosyo-kültürel etkinliklerin ve eğitim imkânlarının etkisi olduğunu, \%23'ü ise göç etme niyetleri üzerinde sosyo-kültürel etkinlikler ve eğitim imkânlarının etkisi olmadığını dile getirmiştir.

Kamu çalışanlarının yüksek düzeyde göç etme niyeti taşıdığı ilçede, personelin özlük hakları ve ödeneklerinin göç etme niyeti üzerinde çok yüksek düzeyde belirleyici olmadığı sonucuna ulaşılmıştır. İlçede sosyo-kültürel etkinliklerin yetersizliği ile eğitim imkânlarının arzu edilen düzeyde olmaması göç etme niyetini tetikleyen nedenler arasında kabul edilebilir.

\section{Hipotezlere İlişkin Bulgular}

H1: Katılımcıların yaşam memnuniyeti düzeyinin artması, göç etme niyeti üzerinde negatif yönde etki etmektedir.

Yaşam memnuniyeti düzeyinin göç etme niyeti üzerinde etkisi olup olmadığını test etmek için regresyon analizi yapılmıştır. Yaşam memnuniyeti bağımsız değişken iken göç etme niyeti bağımlı değişken olarak ele alınmaktadır.

Tablo 8: Yaşam Memnuniyeti ve Göç Etme Niyeti Regresyon Analizi

\begin{tabular}{|c|c|c|c|c|c|}
\hline $\begin{array}{c}\text { Bağımsız } \\
\text { Değişken }\end{array}$ & $\begin{array}{c}\text { Bağımlı } \\
\text { Değişken }\end{array}$ & Standart B & Sig. & Düzeltilmiş R & $\begin{array}{c}\text { F } \\
\text { Değeri }\end{array}$ \\
\hline $\begin{array}{c}\text { Yaşam } \\
\text { Memnuniyeti }\end{array}$ & $\begin{array}{c}\text { Göç Etme } \\
\text { Niyeti }\end{array}$ & $-0,175$ &, 041 &, 0961 & 4,239 \\
\hline
\end{tabular}

Tablo 8'de anlamlılık düzeyini gösteren "Sig" sütunu incelendiğinde $\mathrm{p}=, 041$ anlamlılık düzeyi, 0,041<0,05 (p<0,05 olacak) olduğu için aralarında anlamlı bir ilişki vardır (Güzel, Gök, ve İşler, 2013: 117-119). Sonuç olarak yaşam memnuniyeti düzeyinin artması, göç etme niyeti üzerinde negatif etkiye sahiptir ve araştırmanın $\mathbf{H}_{\mathbf{1}}$ hipotezi doğrulanmıştır. Araştırmanın sonucuna göre 
yaşam memnuniyeti düzeyinin artması, göç etme niyetinin azaltmasına, yaşam memnuniyeti düzeyinin azalması ise göç etme niyetini artırma yönünde etkiye neden olmaktadır.

$\mathbf{H}_{2}$ : Katılımcıların yaşam memnuniyeti ve göç etme niyeti düzeyleri demografik özelliklere göre farlılık göstermektedir.

$\mathbf{H}_{2 \mathbf{a}}$ : Katılımcıların yaşam memnuniyetleri ile cinsiyetleri arasında anlamlı bir fark vardır. Araştırmaya katılan kamu çalışanlarının yaşam memnuniyeti puanları ortalamalarının cinsiyet değişkenine göre anlamlı bir farklılık gösterip göstermediğini belirlemek amacıyla yapılan tek yönlü varyans analizi (Anova) sonucunda grup ortalamaları arasındaki fark istatistiksel açıdan anlamlı bulunmamıştır $(\mathrm{F}=1,707 ; \mathrm{p}=0,194>0,05)$. Bu sebepten dolayı tablo halinde gösterilmemiştir.

H2b: Katılımcıların yaşam memnuniyetleri ile yaşları arasında anlamlı bir fark vardır. Araştırmaya katılan kamu çalışanlarının yaşam memnuniyeti puanları ortalamalarının yaş değişkenine göre anlamlı bir farklılık gösterip göstermediğini belirlemek amacıyla yapılan tek yönlü varyans analizi (Anova) sonucunda grup ortalamaları arasındaki fark istatistiksel açıdan anlamlı bulunmuştur $(\mathrm{F}=3,320 ; \mathrm{p}=0,013<0,05)$.

Tablo 9: Yaş Değişkeni Açısından Yaşam Memnuniyeti Anova Analizi Sonuçları

\begin{tabular}{|c|c|c|c|c|c|c|}
\hline & Yaş Aralı̆̆ı & N & Ortalama & $\begin{array}{c}\text { Standart } \\
\text { Sapma }\end{array}$ & $\begin{array}{c}\text { F } \\
\text { Değeri }\end{array}$ & $\begin{array}{c}\text { Anlam } \\
\text { Düzeyi (p) }\end{array}$ \\
\hline Yaşam & $18-25$ & 18 & 2,97 &, 8045 & 3,320 &, $\mathbf{0 1 3}$ \\
Memnuniyeti & $26-35$ & 77 & 2,86 &, 6945 & \\
& $36-45$ & 25 & 3,41 &, 5803 & \\
& $46-55$ & 11 & 3,14 &, 8364 & \\
\end{tabular}

Tablo 9'da yer alan yaşam memnuniyeti ile yaş durumu faktörü bağlamında tek yönlü varyans analizi (Anova) sonuçlarına bakıldığında yaş durumu bakımından en yüksek yaşam memnuniyeti ortalaması (X=3,41) 36-45 yaş aralığına sahip katılımcılarda gözlenmektedir.

H2c: Katılımcıların yaşam memnuniyetleri ile medeni durumları arasında anlamlı bir fark vardır.

Araştırmaya katılan kamu çalışanlarının yaşam memnuniyeti puanları ortalamalarının medeni durum değişkenine göre anlamlı bir farklılık gösterip göstermediğini belirlemek amacıyla yapılan t- testi sonucunda grup ortalamaları arasındaki fark istatistiksel açıdan anlamlı bulunmamıştır $(\mathrm{t}=-0,516 ; \mathrm{p}=0,412>0,05)$. Bu sebepten dolayı tablo halinde gösterilmemiştir.

H2d: Katılımcıların yaşam memnuniyetleri ile çocuk sayısı arasında anlamlı bir fark vardır.

Araştırmaya katılan kamu çalışanlarının yaşam memnuniyeti puanları ortalamalarının çocuk sayısı değişkenine göre anlamlı bir farklılık gösterip göstermediğini belirlemek amacıyla yapılan tek yönlü varyans analizi (Anova) sonucunda grup ortalamaları arasındaki fark istatistiksel açıdan anlamlı bulunmamıştır ( $\mathrm{F}=1,123 ; \mathrm{p}=0,349>0,05)$. Bu sebepten dolayı tablo halinde gösterilmemiştir.

$\mathbf{H}_{2 \mathrm{e}}$ : Katılımcıların yaşam memnuniyetleri ile eğitim durumları arasında anlamlı bir fark vardır.

Araştırmaya katılan kamu çalışanlarının yaşam memnuniyeti puanları ortalamalarının eğitim durumu değişkenine göre anlamlı bir farklılık gösterip göstermediğini belirlemek amacıyla yapılan tek yönlü varyans analizi (Anova) sonucunda grup ortalamaları arasındaki fark istatistiksel açıdan anlamlı bulunmamıştır ( $\mathrm{F}=1,197 ; \mathrm{p}=0,313>0,05)$. Bu sebepten dolayı tablo halinde gösterilmemiştir.

H2f: Katılımcıların yaşam memnuniyetleri ile doğum yerleri arasında anlamlı bir fark vardır.

Araştırmaya katılan kamu çalışanlarının yaşam memnuniyeti puanları ortalamalarının doğum yeri değişkenine göre anlamlı bir farklılık gösterip göstermediğini belirlemek amacıyla yapılan t- testi sonucunda grup ortalamaları arasındaki fark istatistiksel açıdan anlamlı bulunmamıştır $(\mathrm{t}=4,743 ; \mathrm{p}=0,407>0,05)$. Bu sebepten dolayı tablo halinde gösterilmemiştir.

$\mathbf{H}_{2 \mathrm{~g}}$ : Katılımcıların yaşam memnuniyetleri ile eşlerinin doğum yerleri arasında anlamlı bir fark vardır.

Araştırmaya katılan kamu çalışanlarının yaşam memnuniyeti puanları ortalamalarının eşlerinin doğum yeri değişkenine göre anlamlı bir farklılık gösterip göstermediğini belirlemek amacıyla yapılan t- testi sonucunda grup ortalamaları arasındaki fark istatistiksel açıdan anlamlı bulunmamıştır $(\mathrm{t}=2,697 ; \mathrm{p}=0,293>0,05)$. Bu sebepten dolayı tablo halinde gösterilmemiştir.

$\mathbf{H}_{2 \mathrm{~h}}$ : Katılımcıların göç etme niyetleri ile cinsiyetleri arasında anlamlı bir fark vardır.

Araştırmaya katılan kamu çalışanlarının göç etme niyeti puanları ortalamalarının cinsiyet değişkenine göre anlamlı bir farklılık gösterip göstermediğini belirlemek amacıyla yapılan tek yönlü varyans analizi (Anova) sonucunda grup ortalamaları arasındaki fark istatistiksel açıdan anlamlı bulunmamıştır $(\mathrm{F}=1,493 ; \mathrm{p}=0,224>0,05)$. Bu sebepten dolayı tablo halinde gösterilmemiştir.

H21: Katılımcıların göç etme niyetleri ile yaş aralığı arasında anlamlı bir fark vardır. 
Araştırmaya katılan kamu çalışanlarının göç etme niyeti puanları ortalamalarının yaş değişkenine göre anlamlı bir farklılık gösterip göstermediğini belirlemek amacıyla yapılan tek yönlü varyans analizi (Anova) sonucunda grup ortalamaları arasındaki fark istatistiksel açıdan anlamlı bulunmamıştır $(\mathrm{F}=1,200 ; \mathrm{p}=0,314>0,05)$. Bu sebepten dolayı tablo halinde gösterilmemiştir.

$\mathbf{H}_{2 \mathrm{i}}$ : Katılımcıların göç etme niyetleri ile medeni durumları arasında anlamlı bir fark vardır.

Araştırmaya katılan kamu çalışanlarının göç etme niyeti ortalamalarının medeni durum değişkenine göre anlamlı bir farklılık gösterip göstermediğini belirlemek amacıyla yapılan t- testi sonucunda grup ortalamaları arasındaki fark istatistiksel açıdan anlamlı bulunmamıştır ( $\mathrm{t}=-1,118 ; \mathrm{p}=0,309>0,05)$. Bu sebepten dolayı tablo halinde gösterilmemiştir.

$\mathbf{H}_{\mathbf{2 j}}$ : Katılımcıların göç etme niyetleri ile çocuk sayıları arasında anlamlı bir fark vardır.

Araştırmaya katılan kamu çalışanlarının göç etme niyeti puanları ortalamalarının çocuk sayısı değişkenine göre anlamlı bir farklılık gösterip göstermediğini belirlemek amacıyla yapılan tek yönlü varyans analizi (Anova) sonucunda grup ortalamaları arasındaki fark istatistiksel açıdan anlamlı bulunmamıştır $(\mathrm{F}=0,622 ; \mathrm{p}=0,647>0,05)$. Bu sebepten dolayı tablo halinde gösterilmemiştir.

$\mathbf{H}_{2 \mathbf{k}}$ : Katılımcıların göç etme niyetleri ile eğitim durumları arasında anlamlı bir fark vardır.

Araştırmaya katılan kamu çalışanlarının göç etme niyeti puanları ortalamalarının eğitim durumu değişkenine göre anlamlı bir farklılık gösterip göstermediğini belirlemek amacıyla yapılan tek yönlü varyans analizi (Anova) sonucunda grup ortalamaları arasındaki fark istatistiksel açıdan anlamlı bulunmamıştır $(\mathrm{F}=1,044 ; \mathrm{p}=0,375>0,05)$. Bu sebepten dolayı tablo halinde gösterilmemiştir.

$\mathbf{H}_{21}$ : Katılımcıların göç etme niyetleri ile doğum yerleri arasında anlamlı bir fark vardır.

Araştırmaya katılan kamu çalışanlarının göç etme niyeti ortalamalarının doğum yeri değişkenine göre anlamlı bir farklılık gösterip göstermediğini belirlemek amacıyla yapılan t- testi sonucunda grup ortalamaları arasındaki fark istatistiksel açıdan anlamlı bulunmamıştır $(\mathrm{t}=-1,588 ; \mathrm{p}=0,611>0,05)$. Bu sebepten dolayı tablo halinde gösterilmemiştir.

$\mathbf{H}_{2 m}$ : Katılımcıların göç etme niyetleri ile eşlerinin doğum yerleri arasında anlamlı bir fark vardır.

Araştırmaya katılan kamu çalışanlarının göç etme niyeti ortalamalarının eşlerinin doğum yeri değişkenine göre anlamlı bir farklılık gösterip göstermediğini belirlemek amacıyla yapılan t- testi sonucunda grup ortalamaları arasındaki fark istatistiksel açıdan anlamlı bulunmamıştır ( $\mathrm{t}=-1,492 ; \mathrm{p}=0,293>0,05)$. Bu sebepten dolayı tablo halinde gösterilmemiştir.

Sonuç olarak ortaya atılan $\mathrm{H}_{2}$ hipotezinin alt hipotezlerinden $\mathrm{H}_{2 \mathrm{~b}}$ hipotezi kabul edilmiştir. $\mathrm{H}_{2 \mathrm{a}}, \mathrm{H}_{2 \mathrm{c}}, \mathrm{H}_{2 \mathrm{~d}}, \mathrm{H}_{2 \mathrm{e}}, \mathrm{H}_{2 \mathrm{f}}, \mathrm{H}_{2 \mathrm{~g}}, \mathrm{H}_{2 \mathrm{~h}}$, $\mathrm{H}_{21}, \mathrm{H}_{2 \mathrm{i}}, \mathrm{H}_{2 \mathrm{j}}, \mathrm{H}_{2 \mathrm{k}}, \mathrm{H}_{21}$ alt hipotezleri reddedilmiştir.

\section{SONUÇ}

$\mathrm{Bu}$ araştırmadan elde edilen bulgular sırasıyla şu şekilde sıralanabilir:

- Araştırmaya katılan kamu çalışanlarının yaşam memnuniyeti düzeylerinin göç etme niyeti üzerine etkisi incelenmiştir. Yaşam memnuniyeti düzeyi ile göç etme niyeti arasında regresyon analizi sonucunda yaşam memnuniyeti düzeyinin göç etme niyetini $p<0,041$ anlamlılık seviyesinde -,175 gibi bir beta katsayısı ile negatif yönde etkilediği görülmektedir.

- $\quad$ Araştırmada bireylerin çoğunluğu $(\% 78,7)$ erkek kamu çalışanlarından oluşmaktadır.

- Araştırmaya katılan bireylerin çoğunluğu $(\% 56,6)$ 26-35 yaş aralığındaki kamu çalışanlarıdır.

- $\quad$ Araştırmaya katılan bireylerin çoğunluğu $(\% 61,8)$ evli kamu çalışanlarıdır.

- Kamu çalışanlarının çoğunluğu $(\% 47,1)$ çocuk sahibi değildir.

- Kamu çalışanlarının eğitim durumuna bakıldığında büyük çoğunluğu $(\% 44,9)$ lisans mezunu kişilerdir.

- Çalışan bireylerin Tortumda çalışma süreleri dikkate alındığında 1-5 yıl arası $(\% 72,1)$ çalışanlardan oluşmaktadır.

- Kamu çalışanlarının doğum yerine bakıldığında çalışanların çoğunluğu $(\% 71,3)$ Tortum dışında farklı bir yerleşim yerinde doğmuştur.

- Kamu çalışanlarının eşlerinin doğum yeri ele alındığında ise yine benzer şekilde $(\% 45,6)$ eşleri de Tortum dışında farklı bir yerleşim yerinde doğmuştur.

- Kamu çalışanlarının büyük çoğunluğu $(\% 80,9)$ lojmanlarda iskân etmemektedir.

- Araştırmaya katılan kamu çalışanlarının büyük çoğunluğu $(\% 80,9)$ Tortumda gayrimenkul sahibi değildir. Benzer şekilde kamu çalışanlarının çoğunluğu $(\% 69,9)$ Tortum dışında da gayrimenkul sahibi değildir.

- Araştırmaya katılan kamu çalışanlarının büyük çoğunluğunun akrabaları $(\% 86,0)$ Tortum dışında iskân etmektedir. Yine benzer şekilde kamu çalışanlarının eşlerinin akrabaları da $(\% 52,9)$ Tortum dışında iskân etmektedir.

- Araştırmaya katılan kamu çalışanlarının çoğunluğunun $(\% 58,8)$ şu anda göç etme niyeti yoktur. Fakat beş yıl içerisinde göç etme niyetleri ele alındığında büyük çoğunluğu $(\% 66,9)$ göç etme niyeti taşımaktadır.

- Yapılan uygulamada kamu çalışanlarının yaşam memnuniyeti düzeylerinin demografik özelliklere göre farklılaşması incelendiğinde yaşam memnuniyeti düzeyleri ile cinsiyet, medeni durum, çocuk sayısı, eğitim 
durumu, doğum yeri, eşlerinin doğum yeri arasında anlamlı bir farklılık bulunamamıştır. Yaşam memnuniyeti düzeyleri ile yaş arasında ise anlamlı bir farklılık bulunmuştur.

- Göç etme niyeti düzeylerinin demografik özelliklere göre farklılaşması incelendiğinde göç etme niyeti düzeyleri ile cinsiyet, yaş, medeni durum, çocuk sayısı, eğitim durumu, doğum yeri ve eşlerinin doğum yeri arasında anlamlı bir farklılık bulunamamıştır. Diğer bir ifade ile kamu çalışanlarının göç etme niyeti düşünceleri benzerdir.

Araştırma sonucu dikkate alındığında; kamu çalışanlarında yaşam memnuniyetinin artması bir yandan çalışanların yerleştikleri bölgeye uyum ve bütünleşmesini sağlarken diğer yandan iç göç niyetlerinin de ertelenmesine veya ortadan kalkmasına neden olabilmektedir. Bu durum aynı zamanda çalışanların iş doyumu ve verimliliklerine de yansımaktadır.

Yaşam memnuniyetini artırma yolunda atılan adımlar; çalışanların yalnızca bulundukları yerleşim yerini terk etme düşüncelerinde azalmaya neden olmayacak ülkenin bölgesel gelişmiş̧lik düzeyine de pozitif katkı sağlayacağı düşünülmektedir.

Kamu çalışanlarının yüksek düzeyde göç etme niyeti taşıdığı ilçede, personelin özlük hakları ve ödeneklerinin yüksek düzeyde belirleyici olmadığı sonucuna ulaşılmıştır. Göç niyetinin ortaya çıkmasında ilçenin sosyal ve kültürel etkinliklerin düşüklüğü ile eğitim imkânlarının arzu edilen düzeyde olmaması yüksek düzeyde belirleyici olmuştur.

Bölgede istihdam olunan kamu personeli için kaliteli ve yeter sayıda lojman sağlanmalıdır. Yine bu bağlamda inşa edilecek cazip fiyatlı lüks konutlar yapılarak bir yandan yaşanılan çevrenin standartları yüksek hale getirilmeli, diğer taraftan kamu personellinin yaşadığ 1 şehri sahiplenmesi ve benimsemesine katkıda bulunacak bu konutlar kendilerine satılmalıdır. Zira daha önceki çalışmalarımızda da görüleceği üzere şehir dışı yatırımları bulunan kamu personelinin, göç etme niyeti, yükselmektedir (Küçükali, 2016: 59-79).

Özellikle gelişmişlik düzeyi görece daha düşük olan ülkemizin doğusunda yer alan bölgelerde yaşanmakta olan göç sorunu bütüncül ve sistematik bir şekilde ele alınmalıdır. Tortum ilçesi ve bölgenin gelişmişlik düzeyi ile imkânlarının kısıtlılığı çocuk, eş ve yakınlarının yaralanacağı sosyal donatılar ve eğitim kurumlarının yetersizliği, kamu yatırımlarının düşüklüğü, göç niyetinin oluşumuna etki eden temel unsurlar arasında olduğu sonucuna ulaşılmıştır. Bölgenin sosyo-ekonomik yapısına uygun, etkin ve gerçekçi stratejik sosyal politikaların uygulamaya konulması göç niyetinin ortaya çıkmasını azaltabilecektir.

\section{KAYNAKÇA}

Akıncı, B., Nergiz, A. \& Gedik, E. (2015). Uyum Süreci Üzerine Bir Değerlendirme: Göç ve Toplumsal Kabul. Göç Araştırmaları Dergisi, 1(2), 58-83.

Arslan, E. (2012). Etnik Farklılık, Kendini Anlamlandırma ve Göç; Denizli’ye Doğudan Göç Eden Kadın ile Batıdan Göç Eden Kadının Kimlik ve Cinsiyet Deneyimleri, (Yayımlanmamış Yüksek Lisans Tezi). Denizli: Pamukkale Üniversitesi Sosyal Bilimler Enstitüsü.

Atik, A., Taçoral, E. \& Altunkasa, M.F. (2014). Kent Halkının Kentsel Yaşam Memnuniyeti Üzerinde Etkili Sosyo-demografik Özelliklerinin Belirlenmesi Üzerine Bir Araştırma: Kemaliye Örneği. İnönü Üniversitesi Sanat ve Tasarım Dergisi, 4(9), 21-33.

Behlau, S. (2010). Life Satisfaction: A study of Undergraduate and Graduate Student. (Master'sdissertation, University of Rowan). https://rdw.rowan.edu/cgi/viewcontent.cgi?article= 1035\&context=etd, Erişim tarihi: 18.09.2021.

Bjornskov, C., Dreher, A. \& Fischer, J.A. (2008). Cross- country Determinants of Life Satisfaction: Exploring Different Determinants Across Group in Society. Social Choice and Welfare, 30(1), 119-173.

Boylu, A. A., \& Paçacıŏlu, B. (2016). Yaşam kalitesi ve göstergeleri. Akademik Araştırmalar ve Çalışmalar Dergisi (AKAD), 8(15), 137-150.

Bülbül, Ş. \& Giray, S. (2012). İş ve Özel Yaşam (iş dışı yaşam) Memnuniyeti Arasındaki İlişki Yapısının Doğrusal Olmayan Kanonik Korelasyon Analizi İle İncelenmesi. Anadolu Üniversitesi Sosyal Bilimler Dergisi, 12(4), 101-114.

Can, Y. (2011). Göç ve Kent: 1989’dan Günümüze Göç Eden Insanların Kent Adaptasyonu Diyarbakır Örneği (Yayımlanmamış Yüksek Lisans Tezi). Konya: Selçuk Üniversitesi Sosyal Bilimler Enstitüsü. Çak1, A. (2018). Geçmişten Bugüne Türkiye’nin Göç Politikası ve Suriyeli Göçmenler Bağlamında Göç Yönetişimi (Yayımlanmamış Yüksek Lisans Tezi). Karaman: Karamanoğlu Mehmetbey Üniversitesi Sosyal Bilimler Enstitüsü.

Çelebi, Ö. (2016). Göç ve Kentleşme: Digorlu Pazarcılar Örneği (Yayımlanmamış Yüksek Lisans Tezi). İstanbul: Yıldız Teknik Üniversitesi Sosyal Bilimler Enstitüsü.

Çınar, Y.K. (2018). Küresel Göç Sorunları ve Birleşmiş Milletler ( Yayımlanmamış Yüksek Lisans Tezi). İstanbul: İstanbul Ticaret Üniversitesi Sosyal Bilimler Enstitüsü.

Ekici, S. \& Tuncel, G. (2015). Göç ve İnsan. Birey ve Toplum Dergisi, 5(9), 9-22.

Erol, M. \& Ersever, O.G. (2014). Göç Krizi ve Göç Krizine Müdahale. KHO Bilim Dergisi, 24(1), 47-68.

Frijns, M. (2010). Determinants of Life Satisfaction. (Maastricht University School of Business and Economics Thesis), Netherlands. https://scholar.google.com.tr/scholar?q=Determinants+ 
of+Life+Satisfaction.+(Maastricht+University+School+of+Business+and+Economics+Thesis),\&hl=tr\&as_sdt=0\&as_vis $=1 \& o i=$ scholart. Erişim tarihi: 01.09.2021.

Gül, S. (2017). Mutluluk Ekonomisi ve Göç Üzerine Bir Inceleme (Yayımlanmamış Doktora Tezi). İstanbul: Marmara Üniversitesi Sosyal Bilimler Enstitüsü.

Jagodzinski, W. (2010). Economic, Social and Sultural Determinants of Life Satisfaction: Are there Differences between Asia and Europa?. Social Indicators Research, 97(1), 85-104.

Kahyaoğlu, O. (2008). Yaşam Memnuniyeti ve Yaşam Memnuniyetini Etkileyen Değişkenler ile Ekonometrik Uygulama: Türkiye Örneği, (Yayımlanmamış Yüksek Lisans Tezi). İzmir: Dokuz Eylül Üniversitesi Sosyal Bilimler Enstitüsü.

Karakul Meral, Z. (2010). İnme Geçirmiş Yaşlı Kişilerde Aktivite, Katılım ve Depresyonun Yaşam Memnuniyeti İle Olan İlişkisi (Yayımlanmamış Yüksek Lisans Tezi), Ankara: Hacettepe Üniversitesi Sağlık Bilimleri Enstitüsü.

Koçak, Y. \& Terzi, E. (2012). Türkiye'de Göç Olgusu, Göç Edenlerin Kentlere Olan Etkileri ve Çözüm Önerileri.Kafkas Üniversitesi İktisadi ve İdari Bilimler Dergisi, 3(3), 163-184.

Küçükali, A. (2016). Bir Sosyal Politika Problemi Olarak Göç (Erzurum Örneği). Ankara: İmaj Kitabevi.

Küçükali, A. (2018). Akademisyenlerde Göç Etme Niyeti. Emek ve Toplum Dergisi, 7(19),587-607.

Maria, B. (2015). Nationalstrategy of Immigration: between Proposed Objectives and their Accomplishment. Procedia Economics and Finance, 32, 450-456.

Öztürk, M. (2015). “Sosyolojik Açıdan Suç Korkusu ve Yaşam Memnuniyeti: Mersin İli Örneği” (Yayımlanmamış Doktora Tezi). Sivas: Cumhuriyet Üniversitesi Sosyal Bilimler Enstitüsü.

Paydak, A. (2012). Küreselleşme ile Değişen Göç Kavramı: Yasadışı Göç ve Türkiye'de Adana İli Örneği. (Yayımlanmamış Yüksek Lisans Tezi). Adana: Sosyal Bilimler Enstitüsü.

Ragheb, M., C.A., Griffith (1982). The Contribution of Leisure Participation and Leisure Satisfaction to Life Satisfaction of Older Persons. Journal of Leisure Research, 14, 295-306.

Rainey, L.A. (2017). The Relatıonshıp between Life Satısfactıon, Learner Engagement and Academic Performance in Adolescents in Selected Public Secondary Schools in Windhoek, Namibia. http://repository.unam.edu.na/bitstream/handle/11070/2233/rainey2017.pdf? sequence= 1\&isAllowed=y., Erişim tarihi: 15.09.2021.

Sayın, Y. Usanmaz, A. \& Aslangiri, F. (2016). Uluslararası Göç Olgusu ve Yol Açtı̆̆ı Etkiler: Suriye Göçü Örneği. KMÜ Sosyal ve Ekonomik Araştırmalar Dergisi, 18(31), 1-13.

Toker, B. (2012). Life Satisfation among Academicians: An Empirical Study on the Universities of Turkey. Procedia-Social and Behavioral Sciences, 47, 190-195.

Taş, H.Y., Özcan, S. (2013). Türkiye'de İç Göçün Yoksulluğa ve İstihdama Etkileri. Internatıonal Conference On Eurasıan Economies, 289-298.

Tolstrup, T. (2016). Under Standing Climate Migration.https://curis.ku.dk/ws/files/162169356/ Understanding_climate migration_Thesis2016_Tine_Tolstrup_Final_Version.pdf. Erişim tarihi: 15.09.2021.

Topçu, S. \& Beşer, A. (2006). Göç ve Sağl1k. C.Ü. Hemşirelik Yüksekokulu Dergisi, 10(3), 37-42.

Yenginar, M.M. (2019). Mülteci Aileler ve Göç İle Değişen Aile Yapısı. (Yayımlanmamış Yüksek Lisans Tezi). Konya: Selçuk Üniversitesi Sosyal Bilimler Enstitüsü.

Yetim, B. (2018). Yaşam Memnuniyeti ve Yaşam Kalitesinin Belirleyicileri: Să̆lık Hizmetlerinden Memnuniyet ve Sağllk Statüsünün Rolü (Yayımlanmamış Yüksek Lisans Tezi) Ankara: Hacettepe Üniversitesi Sosyal Bilimler Enstitüsü.

Yılmaz, G. Keser, A. \& Yorgun, S. (2010). Konaklama İşletmelerinde Çalışan Sendika Üyelerinin İş ve Yaşam Doyumunu Belirlemeye Yönelik Bir Alan Araştırması. Paradoks Ekonomi Sosyoloji ve Politika Dergisi, 6 (1), 87-107.

Yücel, Y.B. (2017). Yaşam Memnuniyetini Etkileyen Faktörlerin Sinıflama Ve Regresyon Ăgacı İle Belirlenmesi, (Yayımlanmamış Yüksek Lisans Tezi). İstanbul: İstanbul Ticaret Üniversitesi Fen Bilimleri Enstitüsü. 